Arq. Bras. Med. Vet. Zootec., v.56, n.3, p.281-291, 2004

\title{
Effects of lidocaine on lipopolysaccharide-induced synovitis in horses
}

\author{
[Efeitos da lidocaína em sinovite induzida por lipopolissacarídeo, em eqüinos] \\ R.C. Campebell ${ }^{1}$, J.R. Peiró ${ }^{2}$, C.A.A. Valadão ${ }^{3}$, A.E. Santana ${ }^{3}$, F.Q. Cunha ${ }^{4}$ \\ ${ }^{1}$ Departamento de Medicina Veterinária da UPIS \\ SEP Sul EQ 712/912 Conj. A \\ 70390-125 - Brasília, DF \\ ${ }^{2}$ Curso de Medicina Veterinária. Universidade Estadual Paulista - UNESP - Araçatuba, SP \\ ${ }^{3}$ Faculdade de Ciências Agrárias e Veterinárias. Universidade Estadual Paulista - UNESP - Jaboticabal, SP \\ ${ }^{4}$ Faculdade de Medicina de Ribeirão Preto. Universidade de São Paulo - Ribeirão Preto, SP
}

\begin{abstract}
Lidocaine (100mg $2 \%$ ) injected into the carpal joint was used to evaluate the inflammatory response induced by injection (1.5ng) of intra-articular E. coli lipopolysaccharide (LPS) endotoxin. Seventeen male Mangalarga horses aged two to three years were divided into three groups and in all animals was injected $0.9 \%$ saline (SAL) in the left carpus (LC), and in the right carpus (RC) one of the following combinations were injected: group A $(n=6)$ LPS plus SAL; group B $(n=6)$ LPS plus lidocaine; group C $(n=5)$ lidocaine plus SAL. Synovial fluid and blood samples were collected immediately before the injection of LPS (T0), and at 1.5 (T1), 3 (T2), 6 (T3), 12 (T4) and 36 hours (T5) after the injection. Clinical and physical variables and cellular and biochemical characteristics of the synovial fluid were evaluated at the same time. The local and systemic inflammatory response was evaluated by measurement of mean serum and synovial fluid TNF- $\alpha$ concentration. A rise in TNF- $\alpha$ concentration in LPS injected joints at $3 \mathrm{~h}$ in group A and from $1.5 \mathrm{~h}$ to $3 \mathrm{~h}$ in group B was observed. It is concluded that LPS triggered an inflammatory process and that lidocaine did not inhibit or attenuate the LPS-induced synovitis nor the synthesis and release of TNF- $\alpha$.
\end{abstract}

Keywords: horse, synovitis, lipopolysacharide, TNF- $\alpha$, lidocaine

\section{RESUMO}

Injetou-se lidocaína (100mg 2\%) na articulação do carpo para avaliar a resposta inflamatória induzida pela injeção (1,5ng) intra-articular de lipopolissacarídeo (LPS) de E. coli. Utilizaram-se 17 cavalos Mangalarga não castrados, entre dois e três anos, divididos em três grupos. No carpo esquerdo (CE) administrou-se solução fisiológica a 0,9\% (SAL) e no carpo direito (CD) uma das seguintes combinações: grupo A $(n=6)$ LPS mais SAL, grupo $B(n=6)$ LPS mais lidocaína e grupo $C(n=5)$ lidocaína mais SAL. Amostras do líquido sinovial e de sangue foram colhidas imediatamente antes da injeção de LPS (T0) e às 1,30 (T1), 3 (T2), 6 (T3), 12 (T4) e 36 horas (T5) após a injeção. Variáveis clínicas e físicas, e características bioquímicas e celulares do líquido sinovial foram avaliadas nos mesmos tempos. A resposta inflamatória local e sistêmica foi mensurada pela concentração do TNF- $\alpha$ no soro e líquido sinovial. Observou-se aumento da concentração do TNF- $\alpha$ nas articulações injetadas com LPS às $3 h$ no grupo $A$ e de 1,30 às $3 h$ no grupo B. Concluiu-se que o LPS induziu o processo inflamatório e que a lidocaína não inibiu nem atenuou a sinovite induzida pelo LPS, nem a síntese e liberação de TNF- $\alpha$.

Palavras-chave: eqüino, sinovite, lipopolissacarideo, $T N F-\alpha$, lidocaína

Apoio financeiro FAPESP (96/2787-0)

Recebido para publicação em 28 de junho de 2003

Recebido para publicação, após modificações, em 29 de dezembro de 2003

E-mail: campbell@unb.br 


\section{INTRODUCTION}

Musculoskeletal injuries involving distal limb joints remain the greatest cause of loss of athletic performance in racehorses industry (Todhunter and Lust, 1992). Among these, a common presentation is primary synovitis (Palmer, Bertone, 1994) usually located in the carpal and metacarpo/metatarsophalangeal joint of young horses in active training (McIlwraith, 1987).

The interaction between the synovium and articular cartilage is complex, in vitro and in vivo evidence suggests that structural and functional alterations in the articular tissues intimately affect the other tissues of the joint (Snyderman, 1986). These studies indicate that release of proteases with degrading activities is responsible for damaging the articular cartilage (Saklatvala, 1986). The secretion of these proteases is induced by several cytokines produced locally by macrophages and synovial cells (Dayer et al., 1985; Campbell et al., 1990). In addition, cytokines are especially important as mediators of inflammatory responses. Interleukin-1 (IL-1) and tumor necrosis factor (TNF) have been documented to contribute to joint destruction by induction of degrading proteases and by inducing synovial cells, synovial fibroblasts, and chondrocytes to secrete prostaglandin $\mathrm{E}_{2}$ (Dayer et al., 1985; Campbell et al., 1990); these cytokines have also been associated with synovitis induced by endotoxin in horses (Price et al., 1992; Hawkins et al., 1993). During the initial phase of synovitis induced by intraarticular administration of endotoxin in horses, TNF was one of the first cytokines secreted into the joint fluid (Hawkins et al., 1993).

The use of an experimental model involving small doses of E. coli lipopolysaccharide (LPS) endotoxin aseptically injected into the carpal joint induced a mild to moderate synovitis with clinical signs representative of typical clinical cases (Palmer and Bertone, 1994).

Lidocaine, an amide local anesthetic, has been shown to alter the inflammatory response (Peck et al., 1985; Sasagawa, 1991). Lidocaine has inhibitory effects on neutrophil and macrophage function (Peck et al., 1985; Sasagawa et al., 1991), on the platelet aggregation, and decreases serum levels of $\mathrm{TxB}_{2}$ (Kirichenko et al., 1986; Korth et al., 1985).
It was observed in dogs administered $1 \mathrm{mg} / \mathrm{kg}$ lidocaine IV offered protection against endotoxic shock induced by LPS leading to survival, decreased plasma fibrinogen concentration (Fletcher and Ramwell, 1978) and decreased binding of endotoxin to cell membranes (Garnett et al., 1984). In the same specie, given intravenous prior to injection of monosodium urate crystals into knee joints caused inhibited leukocyte migration and phagocytosis (Paul et al., 1983). Intravenous lidocaine pretreatment also had a prophylactic effect on endotoxininduced lung injury in rabbits (Mikawa et al., 1994).

The use of intra-articular lidocaine for the treatment of equine synovitis has not been reported previously. Because of the lidocaine anti-inflammatory properties in systemic administration through impairment of the superoxide anion $\left(\mathrm{O}_{2}^{-}\right)$release, interference with the binding of endotoxin to cell membranes, inhibition of leukocyte migration and phagocytosis (Korth et al., 1985), this study was performed to evaluate the effects of intraarticular lidocaine administration on LPSinduced synovitis in the carpal joint, and the local and systemic inflammatory responses as characterized by measurement of serum and synovial fluid TNF- $\alpha$ concentration.

\section{MATERIALS AND METHODS}

Seventeen healthy male Mangalarga horses aged two to three years were divided into three groups: A $(n=6), B(n=6)$, and $C(n=5)$. All animals were maintained in stalls and received hay and water ad libitum. Before the beginning of the study, temperature, cardiac and respiratory rate, hematology and an orthopedic examination to rule out pre-existing musculoskeletal injuries were performed in all horses. The right (RC) and left (LC) carpal joints were aseptically prepared. The research was approved by the FCAVUNESP Animal Care Committee.

To induction of synovitis a total volume of $6.5 \mathrm{ml}$ was injected into each joint according to the following schedule: group A (1.5ng of $\mathrm{LPS}^{1}+0.9 \%$ saline in the RC and $0.9 \%$ saline in the LC); group B (1.5ng of LPS $+100 \mathrm{mg}$ of

${ }^{1}$ LPS E. coli 055:B5 - Sigma Chemical CO., St. Louis, USA. 
lidocaine $2 \%$ in the $\mathrm{RC}$ and $0.9 \%$ saline in the LC) and group C (100mg of lidocaine 2\%+0.9\% saline in the RC and $0.9 \%$ saline and $\mathrm{LC}$ ).

Samples of venous blood $(10 \mathrm{ml})$ and synovial fluid $(3 \mathrm{ml})$ were collected immediately before the injection of LPS (T0), and subsequently at 1.5 (T1), 3 (T2), 6 (T3), 12 (T4) and 36 hours (T5) after injection of LPS. Clinical variables were evaluated at the same times, and rectal temperature, heart and respiratory rate, mucous membrane color and capillary refill time were recorded. Joint effusion was assessed by measuring joint circumference, and heat and resistance to palpation were subjectively assessed at the same time. The grade of lameness was scored on a range from 1 (lameness detected only at a trot) to 4 (non-weight-bearing lameness) (Stashak, 1987). Blood samples from the jugular vein were obtained and used for hematology analysis (hematocrit and complete white blood cell count), and to determine the total protein and glucose concentrations in plasma. Arthrocentesis from the flexed intercarpal joint were performed with sterile (20 gauge $\times 2.5 \mathrm{~cm}$ ) hypodermic needles, syringes $(20 \mathrm{ml})$ and gloves. Synovial fluid was evaluated in terms of physical characteristics (aspect, color), specific gravity, cellularity (red blood cell, complete white blood cell count), and biochemical characteristics (total protein, albumin, mucin precipitate, glucose, alkaline phosphatase, aspartate aminotransferase and lactate dehydrogenase), as indicated by Van Pelt (1974). Mucin precipitate quality was classified as regular to poor according to Van Pelt (1974).

Measurement of TNF- $\alpha$ assay, using WEHI 164 clone 13 cells in blood and synovial fluid was used. The assay was a modification of that described previously (Espervik and NissenMeyer, 1986).

Data are reported as means \pm SEM and were analyzed using ANOVA. Blood data were analyzed by split plots in time with units (treatments: groups A, B and C) and subunits (times: T0, T1, T2, T3, T4, T5), in a completely randomized design with six replicates. Synovial fluid data were analyzed, by split plots in times with factorial scheme in units (three treatments, groups $\mathrm{A}, \mathrm{B}$ and $\mathrm{C}$; two sides: right and left carpus) and subunits (times: T0, T1, T2, T3, T4, $\mathrm{T} 5$ ), in a completely randomized design with six replicates. Mean comparisons were made by Tukey's test; differences were considered significant at $\mathrm{P} \leq 0.05$ (User's..., 1996).

\section{RESULTS}

Appetite and water intake were unaffected by intra-articular LPS injection. Heart rate, respiration, mucous membrane color, capillary refill time and temperature remained normal except for a statistically, but not clinically significant transient increase in temperature $\left(38.8^{\circ} \mathrm{C}\right)$ between 6 and $12 \mathrm{~h}$ in group A. Warmth joints, increased sensitivity and mild to moderate joint effusion with an enlargement of the joint circumference, statistically significant, were observed at $36 \mathrm{~h}$ in all groups, measuring $1.0 \mathrm{~cm}$ above the baseline value in the right carpus $(0.92$ to $1.73 \mathrm{~cm}$ ) and in the left carpus was lesser than $1.0 \mathrm{~cm}(0.75$ to $0.87 \mathrm{~cm})$. Signs of effusion began to wane and were completely resolved after $48 \mathrm{~h}$. Lameness scores ranged from 0 to 2 (lameness detected only at a trot), detected only in the RC of A and B groups, between 3 and 36h. All horses continued to bear weight on the injected limb throughout the $36 \mathrm{~h}$. They received a score of zero prior to arthrocentesis, and the score returned to zero by $48 \mathrm{~h}$.

A significant increase in red blood cells (RBC) occurred at 12 and $36 \mathrm{~h}$, respectively, in groups A and $\mathrm{B}$, but the hematocrit did not change (Table 1 ). White blood cells (WBC) were significantly increased at $36 \mathrm{~h}$ in group A and between 6 and $12 \mathrm{~h}$ in group B. Circulating neutrophil counts were significantly higher than the baseline value between 3 and $12 \mathrm{~h}$ in group A, and at 6 and $12 \mathrm{~h}$ in group B. Lymphocyte counts were significantly decreased in the same time that neutrophils were increased in group A. Total plasma protein concentration increased significantly at $36 \mathrm{~h}$ in group A and from $6 \mathrm{~h}$ in group B. Plasma glucose concentration did not change.

${ }^{2}$ Xylestesin - Cristália Produtos Químicos e Farmacêuticos Ltda., Itapira, São Paulo, Brasil. 
Table 1. Mean number \pm standard deviation of red blood cells $(\mathrm{RBC})\left(\times 10^{3} / \mathrm{mm}^{3}\right)$, white blood cells (WBC) $\left(\right.$ cells $\left./ \mathrm{mm}^{3}\right)$, circulating neutrophil (Neut) $\left(\right.$ cells $\left./ \mathrm{mm}^{3}\right)$, lymphocyte (Lymp) $\left(\right.$ cells $\left./ \mathrm{mm}^{3}\right)$ and total plasma protein (TPP) (g/dl) of horses after E. coli lipopolysaccharide (LPS) carpus injections $1.5 \mathrm{ng}+$ saline (SAL) (group A); LPS 1.5ng + lidocaine (lid) 100mg (group B) e lid 100mg + SAL $5 \mathrm{ml}$ (group C) into the right carpus (RC) and $6.5 \mathrm{ml} \mathrm{SAL}$ into the left carpus (LC) in groups A, B and C, in horses

\begin{tabular}{|c|c|c|c|c|c|c|c|}
\hline \multirow{2}{*}{ Blood cell } & \multirow{2}{*}{ Group } & \multicolumn{6}{|c|}{ Time (hours) } \\
\hline & & $0-0: 00$ & $1-1: 30$ & $2-3: 00$ & $3-6: 00$ & $4-12: 00$ & $5-36: 00$ \\
\hline \multirow{3}{*}{$\mathrm{RBC}$} & $\mathrm{A}(\mathrm{n}=6)$ & $7622 \pm 681$ & $6573 \pm 271$ & $6563 \pm 155$ & $7053 \pm 200$ & $9220 \pm 695 *$ & $8129 \pm 365$ \\
\hline & $B(n=6)$ & $6760 \pm 531$ & $7162 \pm 676$ & $6883 \pm 293$ & $7347 \pm 246$ & $8075 \pm 478$ & $10138 \pm 910 *$ \\
\hline & $C(n=5)$ & $8206 \pm 476$ & $8654 \pm 427^{+}$ & $8048 \pm 255^{+}$ & $8800 \pm 813^{+}$ & $10600 \pm 985$ & $9854 \pm 730$ \\
\hline \multirow{3}{*}{ WBC } & $A(n=6)$ & $9333 \pm 998$ & $10883 \pm 895$ & $11517 \pm 902$ & $12800 \pm 1158$ & $11467 \pm 1493$ & $13567 \pm 904 *$ \\
\hline & $B(n=6)$ & $10250 \pm 587$ & $11783 \pm 747$ & $12667 \pm 745$ & $14167 \pm 732 *$ & $14700 \pm 1294 *$ & $11367 \pm 2109$ \\
\hline & $C(n=5)$ & $10800 \pm 389$ & $11060 \pm 524$ & $11420 \pm 836$ & $13760 \pm 1023$ & $11960 \pm 670$ & $14080 \pm 1196$ \\
\hline \multirow{3}{*}{ Neut. } & $A(n=6)$ & $4194 \pm 631$ & $5639 \pm 489$ & $7275 \pm 971 *$ & $9188 \pm 1219 *$ & $7230 \pm 1252 *$ & $6462 \pm 901$ \\
\hline & $B(n=6)$ & $3760 \pm 331$ & $5033 \pm 612$ & $6549 \pm 636$ & $8808 \pm 824 *$ & $7762 \pm 757^{*}$ & $4905 \pm 1614$ \\
\hline & $C(n=5)$ & $5331 \pm 361$ & $5830 \pm 173$ & $6148 \pm 481$ & $8656 \pm 1296$ & $6470 \pm 557$ & $7235 \pm 1338$ \\
\hline \multirow{3}{*}{ Lymp. } & $A(n=6)$ & $5080 \pm 732$ & $4878 \pm 401$ & $3939 \pm 252 *$ & $3280 \pm 270 *$ & $3869 \pm 537 *$ & $6544 \pm 539$ \\
\hline & $B(n=6)$ & $6322 \pm 617$ & $6431 \pm 599$ & $5971 \pm 624$ & $5059 \pm 251 *$ & $6647 \pm 601 *$ & $6300 \pm 1009$ \\
\hline & $C(n=5)$ & $5145 \pm 654$ & $4657 \pm 497$ & $5207 \pm 657$ & $4865 \pm 649$ & $5184 \pm 542$ & $6670 \pm 813$ \\
\hline \multirow{3}{*}{ ТPP } & $A(n=6)$ & $8.24 \pm 0.2$ & $7.95 \pm 0.2$ & $8.05 \pm 0.3$ & $7.74 \pm 0.3$ & $8.35 \pm 0.2$ & $8.52 \pm 0.2 *$ \\
\hline & $\mathrm{B}(\mathrm{n}=6)$ & $7.18 \pm 0.3$ & $7.42 \pm 0.3$ & $7.25 \pm 0.3$ & $7.63 \pm 0.2 *$ & $8.24 \pm 0.2 *$ & $7.93 \pm 0.2 *$ \\
\hline & $C(n=5)$ & $7.79 \pm 0.2$ & $7.99 \pm 0.3$ & $7.86 \pm 0.3$ & $7.96 \pm 0.2$ & $7.77 \pm 0.3$ & $7.38 \pm 0.1$ \\
\hline
\end{tabular}

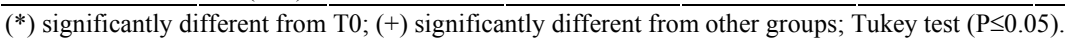

The visual aspect, color and specific gravity of the synovial fluid did not change in the LC in control group $\mathrm{C}$, but specific gravity increased in both RC and LC in groups A and B. In group $\mathrm{B}$ there was a significant difference in specific gravity between RC and LC at $36 \mathrm{~h}$.

A significant increase in RBC in LPS injected joints (RC) was observed at $3 \mathrm{~h}$ in group $\mathrm{A}$ and between 3 and $12 \mathrm{~h}$ in group B (Table 2). In group B, there was a significant difference from the groups $\mathrm{A}$ and $\mathrm{C}$ at $1.5 \mathrm{~h}$. In the $\mathrm{LC}$, the increase was not different to $\mathrm{RC}$, but in group $\mathrm{B}$ it occurred up to $6 \mathrm{~h}$ only. WBC increased from
$3 \mathrm{~h}$ in both LPS injected joints, and at $3 \mathrm{~h}$ in group $\mathrm{C}$ in the RC (Table 3). LPS injected groups were different from the group $\mathrm{C}$ between 6 and $36 \mathrm{~h}$. In the LC, the increase occurred at $6 \mathrm{~h}$ in group A, between 6 and $36 \mathrm{~h}$ in group B and at $36 \mathrm{~h}$ in group $\mathrm{C}$. The values at $3 \mathrm{~h}$ following LPS injection in group $\mathrm{A}$, and between 6 and $12 \mathrm{~h}$ in group $\mathrm{B}$, in the $\mathrm{RC}$ were significantly different from the LC. Polymorphonuclear cells (PMN) were significantly increased between 6 and $12 \mathrm{~h}$ after LPS injection in all groups of the LC at the same time. Mononuclear cells (MN) decreased at the same times as the PMN increased.

Table 2. Mean number \pm standard deviation of erythrocytes in the synovial fluid $\left(\times 10^{3} / \mathrm{mm}^{3}\right)$ of horses after E. coli lipopolysaccharide (LPS) carpus injections $1.5 \mathrm{ng}+$ saline (SAL) (group A); LPS 1.5ng + lidocaine (lid) 100mg (group B) e lid 100mg + SAL 5ml (group C) into the right carpus (RC) and $6.5 \mathrm{ml}$ SAL into the left carpus (LC) in groups A, B and C, in horses

\begin{tabular}{|c|c|c|c|c|c|c|c|}
\hline \multirow{2}{*}{ Side } & \multirow{2}{*}{ Group } & \multicolumn{6}{|c|}{ Time (hours) } \\
\hline & & $0-0: 00$ & $1-1: 30$ & $2-3: 00$ & $3-6: 00$ & $4-12: 00$ & $5-36: 00$ \\
\hline \multirow{3}{*}{$\mathrm{RC}$} & $A(n=6)$ & $342 \pm 443$ & $623 \pm 408$ & $750 \pm 496^{*}$ & $628 \pm 535$ & $298 \pm 217$ & $663 \pm 814$ \\
\hline & $B(n=6)$ & $82 \pm 79$ & $845 \pm 527+$ & $2893 \pm 2639 *$ & $1433 \pm 907^{*}$ & $908 \pm 519^{*}$ & $498 \pm 214$ \\
\hline & $C(n=5)$ & $54 \pm 53$ & $106 \pm 70$ & $1670 \pm 1932$ & $848 \pm 1279$ & $846 \pm 982$ & $463 \pm 558$ \\
\hline \multirow{3}{*}{$\mathrm{LC}$} & $A(n=6)$ & $187 \pm 230$ & $267 \pm 226$ & $1148 \pm 989 *$ & $890 \pm 596$ & $492 \pm 531$ & $660 \pm 860$ \\
\hline & $B(n=6)$ & $80 \pm 58$ & $548 \pm 501$ & $2297 \pm 3274 *$ & $2943 \pm 2369^{*}$ & $1400 \pm 991$ & $1257 \pm 1321$ \\
\hline & $C(n=5)$ & $108 \pm 114$ & $265 \pm 416$ & $1873 \pm 3123$ & $1368 \pm 2239$ & $2507 \pm 3659$ & $1216 \pm 2015$ \\
\hline
\end{tabular}

$\left(^{*}\right)$ significantly different from $\mathrm{T} 0 ;(+)$ significantly different from other groups in the same side; Tukey test $(\mathrm{P} \leq 0.05)$. 
Table 3. Mean number \pm standard deviation of leukocytes in the synovial fluid $\left(\times 10^{3} / \mathrm{mm}^{3}\right)$ of horses after E. coli lipopolysaccharide (LPS) carpus injections $1.5 \mathrm{ng}+$ saline (SAL) (group A); LPS $1.5 \mathrm{ng}+$ lidocaine (lid) $100 \mathrm{mg}$ (group B) e lid 100mg + SAL $5 \mathrm{ml}$ (group C) into the right carpus (RC) and 6.5ml SAL into the left carpus (LC) in groups A, B and C, in horses

\begin{tabular}{|c|c|c|c|c|c|c|c|}
\hline \multirow{2}{*}{ Side } & \multirow{2}{*}{ Group } & \multicolumn{6}{|c|}{ Time (hours) } \\
\hline & & $0-0: 00$ & $1-1: 30$ & $2-3: 00$ & $3-6: 00$ & $4-12: 00$ & $5-36: 00$ \\
\hline \multirow{3}{*}{$\mathrm{RC}$} & $A(n=6)$ & $0.9 \pm 0.8$ & $3.3 \pm 5.0$ & $39.0 \pm 18.0 * \#$ & $83.8 \pm 24.7 * \#$ & $43.5 \pm 25.5^{*}$ & $14.7 \pm 8.0$ *\# \\
\hline & $B(n=6)$ & $0.3 \pm 0.1$ & $2.7 \pm 2.2$ & $32.5 \pm 19.2 * \#$ & $118.5 \pm 36.8^{* \#}$ & $82.4 \pm 26.9$ *\# & $25.6 \pm 14.3^{*}+\#$ \\
\hline & $C(n=5)$ & $0.3 \pm 0.1$ & $0.5 \pm 0.2$ & $20.0 \pm 15.2 * \#$ & $13.7 \pm 22.9+$ & $14.4 \pm 23.8+$ & $5.4 \pm 4.5$ \\
\hline \multirow{3}{*}{ LC } & $A(n=6)$ & $0.4 \pm 0.2$ & $1.2 \pm 0.8$ & $2.5 \pm 1.6$ & $19.9 \pm 21.8^{*}$ & $22.4 \pm 26.3 *$ & $5.4 \pm 5.7$ \\
\hline & $B(n=6)$ & $0.4 \pm 0.3$ & $2.6 \pm 4.1$ & $3.7 \pm 4.6$ & $18.9 \pm 12.8^{*}$ & $12.9 \pm 7.3^{*}$ & $5.1 \pm 3.3^{*}$ \\
\hline & $C(n=5)$ & $0.4 \pm 0.2$ & $0.6 \pm 0.4$ & $3.9 \pm 5.5$ & $3.4 \pm 3.8$ & $2.7 \pm 0.6$ & $3.7 \pm 2.5^{*}$ \\
\hline
\end{tabular}

(*) significantly different from T0; $(+)$ significantly different from other groups in the same side; (\#) significantly different from left carpus in the same group; Tukey test $(\mathrm{P} \leq 0.05)$.

Total protein concentration (Table 4), increased from $3 \mathrm{~h}$ on in all groups of the RC. In the LC, the increase occurred at $12 \mathrm{~h}$ in group A, after $3 \mathrm{~h}$ in group B and at $12 \mathrm{~h}$ in group C. This increase was greater in groups $\mathrm{A}$ and $\mathrm{B}$ than in $\mathrm{C}$ for the $\mathrm{RC}$ between 6 and $12 \mathrm{~h}$. At $6 \mathrm{~h}$ in group $\mathrm{A}$ and between 6 and $12 \mathrm{~h}$ in group B, the RC values were significantly different from the LC. Albumin concentration increased in the $\mathrm{RC}$ and LC after 3 and $6 \mathrm{~h}$, respectively, in both groups $\mathrm{A}$ and $\mathrm{B}$, and was greater than in $\mathrm{C}$ for the $\mathrm{RC}$. Mucin precipitate was reduced in quality in the $\mathrm{RC}$ of group A by $3 \mathrm{~h}$, and by $6 \mathrm{~h}$ in the $\mathrm{RC}$ of group B. A change was seen in the LC of group $\mathrm{A}$ by $12 \mathrm{~h}$. Glucose concentration decreased in B at 6 and $36 \mathrm{~h}$ for the $\mathrm{RC}$ and in $\mathrm{A}$ at $36 \mathrm{~h}$ for the LC (Table 5). Alkaline phosphatase and lactic dehydrogenase concentrations increased in all groups for the RC and in A and B for the LC.
Enzyme concentrations in $\mathrm{A}$ and $\mathrm{B}$ were greater than in $\mathrm{C}$ in the RC. Aspartate aminotransferase increased in all groups for the $\mathrm{RC}$ and in $\mathrm{A}$ for the LC.

An increased on TNF- $\alpha$ concentration was observed in synovial fluid in RC in group A until 3h. After this time the concentration of this cytokine was decreased. In the RC TNF- $\alpha$ concentration was increased in A group at $3 \mathrm{~h}$ and between $1.5 \mathrm{~h}$ and $3 \mathrm{~h}$ in group B while in the LC there was not a significant increase in this cytokine. Among groups, alterations were not observed. There was a statistical difference between $\mathrm{RC}$ and $\mathrm{LC}$ in groups $\mathrm{A}$ and $\mathrm{B}$ at $1.5 \mathrm{~h}$ and $3 \mathrm{~h}$. No difference was observed in serum TNF- $\alpha$ concentration.

Table 4. Mean number \pm standard deviation of protein levels in the synovial fluid (g/dl) of horses after $E$. coli lipopolysaccharide (LPS) carpus injections $1.5 \mathrm{ng}+$ saline (SAL) (group A); LPS 1.5ng + lidocaine (lid) $100 \mathrm{mg}$ (group B) e lid 100mg + SAL 5ml (group C) into the right carpus (RC) and 6.5ml SAL into the left carpus (LC) in groups A, B and C, in horses

\begin{tabular}{lccccccc}
\hline \multirow{2}{*}{ Side } & \multirow{2}{*}{ Group } & \multicolumn{7}{c}{ Time (hours) } \\
\cline { 3 - 7 } & & $0-0: 00$ & $1-1: 30$ & $2-3: 00$ & $3-6: 00$ & $4-12: 00$ & $5-36: 00$ \\
\hline \multirow{3}{*}{ RC } & A (n=6) & $1.2 \pm 0.5$ & $2.0 \pm 0.3+$ & $3.4 \pm 1.1^{*}$ & $5.8 \pm 1.5^{*} \#$ & $6.7 \pm 1.4^{*}$ & $3.1 \pm 1.3$ \\
& $\mathrm{~B}(\mathrm{n}=6)$ & $1.0 \pm 0.2$ & $1.5 \pm 0.2$ & $4.5 \pm 1.6^{*}$ & $5.8 \pm 1.2^{*} \#$ & $7.1 \pm 1.3^{*} \#$ & $4.1 \pm 0.6^{*}$ \\
& $\mathrm{C}(\mathrm{n}=5)$ & $1.2 \pm 0.3$ & $1.1 \pm 0.2$ & $3.1 \pm 0.0^{*}$ & $2.3 \pm 0.7^{*+}$ & $4.0 \pm 1.0^{*+}$ & $2.5 \pm 0.6^{*}$ \\
& $\mathrm{~A}(\mathrm{n}=6)$ & $1.4 \pm 0.6$ & $1.4 \pm 0.6$ & $4.9 \pm 3.3$ & $4.1 \pm 1.6$ & $6.3 \pm 2.6^{*}$ & $4.6 \pm 4.3$ \\
LC & $\mathrm{B}(\mathrm{n}=6)$ & $1.0 \pm 0.2$ & $1.1 \pm 0.3$ & $2.8 \pm 1.6^{*}$ & $3.5 \pm 1.4^{*}$ & $4.7 \pm 1.5^{*}$ & $4.2 \pm 0.7^{*}$ \\
& $\mathrm{C}(\mathrm{n}=5)$ & $1.1 \pm 0.2$ & $1.3 \pm 0.5$ & $3.0 \pm 1.6$ & $1.9 \pm 0.3$ & $3.1 \pm 1.6^{*}$ & $2.1 \pm 0.3$ \\
\hline
\end{tabular}

$(*)$ significantly different from $\mathrm{T} 0 ;(+)$ significantly different from other groups in the same side; (\#) significantly different from left carpus in the same group; Tukey test $(\mathrm{P} \leq 0.05)$. 
Table 5. Mean number \pm standard deviation of glucose levels in the synovial fluid (mg/dl) of horses after E. coli lipopolysaccharide (LPS) carpus injections $1.5 \mathrm{ng}+$ saline (SAL) (group A); LPS 1.5ng + lidocaine (lid) $100 \mathrm{mg}$ (group B) e lid 100mg + SAL $5 \mathrm{ml}$ (group C) into the right carpus (RC) and 6.5ml SAL into the left carpus (LC) in groups A, B and C, in horses

\begin{tabular}{llcccccc}
\hline \multirow{2}{*}{ Side } & \multirow{2}{*}{ Group } & \multicolumn{7}{c}{ Time (hours) } \\
\cline { 3 - 8 } & & $0-0: 00$ & $1-1: 30$ & $2-3: 00$ & $3-6: 00$ & $4-12: 00$ & $5-36: 00$ \\
\hline \multirow{2}{*}{ RC } & A (n=6) & $108.9 \pm 25.5$ & $101.6 \pm 28.6$ & $70.9 \pm 35.9$ & $83.3 \pm 30.9$ & $78.9 \pm 33.4$ & $55.2 \pm 44.2$ \\
& B (n=6) & $109.1 \pm 18.6$ & $86.2 \pm 17.6 \#$ & $69.7 \pm 27,4 \#$ & $50.5 \pm 28.6^{*}$ & $74.5 \pm 13.0$ & $43.0 \pm 40.9^{*}$ \\
& C (n=5) & $75.0 \pm 50.4$ & $72.4 \pm 38.9$ & $67.9 \pm 50.0$ & $102.4 \pm 53.3$ & $90.8 \pm 39.3$ & $35.5 \pm 30.1$ \\
& A ( $=6)$ & $113.6 \pm 22.1$ & $121.0 \pm 18.3$ & $91.7 \pm 31.4$ & $108.8 \pm 16.7$ & $87.4 \pm 29.8$ & $38.9 \pm 38.2^{*}$ \\
LC & B (n=6) & $98.2 \pm 28.7$ & $115.6 \pm 21.3$ & $112.2 \pm 14.6$ & $67.5 \pm 21.0$ & $111.0 \pm 22.1$ & $59.6 \pm 46.6$ \\
& C (n=5) & $58.8 \pm 45.2$ & $91.5 \pm 55.4$ & $97.5 \pm 47.3$ & $94.4 \pm 37.2$ & $90.6 \pm 49.2$ & $50.4 \pm 39.4$ \\
\hline
\end{tabular}

$\left(^{*}\right)$ significantly different from $\mathrm{T} 0 ;(+)$ significantly different from other groups in the same side; (\#) significantly different from left carpus in the same group; Tukey test $(\mathrm{P} \leq 0.05)$.

\section{DISCUSSION}

The findings of this study are in accordance with Bertone $(1996)^{3}$, where it was described that a dose of $1.5 \mathrm{ng}$ of LPS injected intra-articularly in the middle carpal joint was able to induce synovitis clinically similar to the acute synovitis, with synovial fluid total nucleated cell count, total protein responsiveness, a few clinical effects and without non-weight bearing lameness. Because of these similarities, the administration of small doses of intra-articular $E$. coli (LPS) endotoxin permits the study of possible therapeutic agents for equine synovitis (Palmer and Bertone, 1994). The absence of clinically significant increased temperature and lameness in these animals, besides the increased leukocytes count in synovial fluid $\left(118.5 \times 10^{3} / \mathrm{mm}^{3}\right)$ were similar to those observed by Palmer and Bertone (1994) $\left(122 \times 10^{9} / 1\right)$ who used a dose of $0.5 \mathrm{ng}$. This demonstrates that the dose used in this study was effective to induce an inflammatory response.

Despite synovial fluid collection, alternation between the dorsolateral and dorsomedial aspects of the intercarpal joint, as indicated by Owens et al. (1996), increased heat, sensitivity as joint effusion were observed in all groups, and probably were related to repeated arthrocentesis, even though Coppo et al. (1988) showed that repeated sampling did not change biochemical findings and cellularity in the synovial fluid. Other authors demonstrated that serial arthrocentesis caused synovial fluid alterations

${ }^{3}$ Personal communication. 2. Veterinary Surgery Congress, Ribeirão Preto - Brazil, 1996.
(Singh, 1991; Hussni et al., 1996). The visual aspect, color and specific gravity alterations of the synovial fluid in the LPS injected joints probably occurred by accumulation of cells into joint as described by Tulamo el al. (1989).

The use of a contralateral limb as a control in this model, as used by Hawkins et al. (1993), showed that probably repeated arthrocentesis induced an enlargement of the carpal joint circumference in both forelimbs, but this increase was two times higher in RC (in group A) than in LC.

The dose of LPS used cause lameness ranging from 1 to 2 in $\mathrm{RC}$ of the groups $\mathrm{A}$ and $\mathrm{B}$, and all horses continued to bear weight on the injected limb throughout the $36 \mathrm{~h}$ following LPS injection. The joint circumference enlargement was similar to those reported by Palmer and Bertone (1994) who used $0.5 \mathrm{ng}$ of LPS/joint had an increase in joint circumference of 1 to $1.5 \mathrm{~cm}>$ baseline, whereas in this study the largest joint circumference of $1.7 \mathrm{~cm}$ was observed in $\mathrm{RC}$ in animals of group A.

Increased $\mathrm{RBC}$ count in synovial fluid, in all groups in $\mathrm{RC}$ and $\mathrm{LC}$, demonstrates the alterations caused by repeated arthrocentesis, where intra-synovial hemorrhage is easily produced by means of trauma to the synovial membrane (Todhunter and Lust, 1990) in the numerous blood vessel present in the subintima and extend to within 5 to $10 \mu \mathrm{m}$ of the intimal surface (McIlwraith, 1990). The significantly increased $\mathrm{RBC}$ in synovial fluid in groups $\mathrm{A}$ and $\mathrm{B}$, in the $\mathrm{RC}$ and $\mathrm{LC}$, along time when compared to time 0 , suggests that the local and systemic effects of LPS, increased the vascular 
permeability of the synovial membrane $3 \mathrm{~h}$ after LPS injection as described by Firth et al. (1987).

The enlargement of carpal joint circumference due to the inflammatory response caused by LPS injection could be confirmed by the increased leukocyte and PMN cell count in group A and in the right forelimbs, which were statistically different from the contralateral limb in the same groups. In the right forelimb, the increased PMN cell count in groups A and B occurred concomitant or subsequent to the increase in TNF- $\alpha$ concentration in synovial fluid at 3 and $1.5 \mathrm{~h}$, respectively. These results are similar to those of Hawkins et al. (1993), which were characterized by an increase in the neutrophil count, typical of an acute inflammatory response where mean TNF- $\alpha$ concentration in synovial fluid was maximal at $2 \mathrm{~h}$ after LPS injection and was not detected in any of the control joint samples.

As in other studies (Wagner et al., 1982; Hawkins et al., 1993), the injection of saline into the control carpal joint of horses, induced an inflammatory response, but these increases were minimal compared with those joints injected with LPS.

Increased synovial fluid total protein and albumin concentrations were observed after $3 \mathrm{~h}$ in all groups, in both joints, but were minor in group C. It is well known that the synovial protein values are approximately 25 to $35 \%$ of the plasma concentration of this element (Van Pelt, 1974) and this was confirmed in the baseline values of our study. During joint inflammation and serial repeated arthrocenteses, an increase in capillary permeability could occur, which allowed higher molecular weight protein fractions, mainly globulins, to enter the joint, resulting in a synovial protein concentration close to that found in the serum (Persson, 1971). The increased synovial fluid total protein and albumin concentrations observed in this study could be due to the inflammatory response to the serial arthrocenteses, an effect further increased by LPS in groups A and B.

The decreased synovial fluid glucose concentration observed in all groups and RC and LC is in accordance with Van Pelt (1974) who described a lesser amount of glucose entering the joint as the severity of the inflammation increases, but this decrease was only significant in group B in the RC. In adult horses under normal conditions, the glucose content in synovial fluid closely parallels that of the serum. With increasing inflammation, synovial fluid glucose content falls below that of the simultaneously measured serum glucose content and may even approach a value of zero. If severe inflammation of a septic nature is suspected, marked synovial fluid-serum glucose differences can be of diagnostic value and maybe could characterize an increase in glucose consumption during inflammation (Persson, 1971).

An increase in synovial fluid alkaline phosphatase and lactic dehydrogenase concentrations in all groups for the RC and in A and B for the LC and of aspartate aminotransferase concentration in all groups for the RC and in A for the LC, probably occurred due to an increased production and release of these biochemical elements during inflammation by leukocytes or by cells within the synovial membrane damaged by the LPS (McIlwraith et al., 1979; Wagner et al., 1982). Alternatively, enzymes released from the synovium may incite the release of other inflammatory factors, such as cytokines, from adjacent synoviocytes and chondrocytes (Palmer and Bertone, 1994).

The LPS dosage used in this study did not elicit any significant change in vital signs during the study, except for rectal temperature which was significantly increased between 6 and $12 \mathrm{~h}$ $\left(0.7^{\circ} \mathrm{C}\right)$ of baseline values $\left(38.2^{\circ} \mathrm{C}\right)$, in horses from group A, possibly due to the direct action of LPS in the thermoregulatory center in the brain and by the synthesis and secretion of endogenous pyrogens from neutrophils and mononuclear phagocytes (Fessler et al., 1989). This increase was similar to that observed by Hawkins et al. (1993). No changes in body temperature were observed in group B, suggesting a lower inflammatory response, probably due to the inhibitory effects on the cellular components mediated by lidocaine, with inhibitory effects on neutrophil and macrophage function (Sasagawa, 1991; Ohsaka et al., 1994), inhibition of phospholipase $A_{2}$ (Kunze et al., 1976) activity or inhibitory cytokine synthesis and/or release, possibly related to a febrile state (Ohsaka et al., 1994). 
The endotoxin injected intra-articularly was sufficient to cause changes in red and white blood cells in peripheral blood. The increased in red blood cell, although still within the normal values, in groups A and B, probably occurred due to stress stimulated by the repeat arthrocenteses or by endotoxin action (Burrows, 1979; Henry and Moore, 1990).

Mild leukocytosis observed by $36 \mathrm{~h}$ in group A and between 6 and $12 \mathrm{~h}$ in group B occurred with changes in neutrophil blood count which were the predominant cells responsible for this trend. These values remained within the normal limits for horses. This was also observed by Hawkins et al. (1993), they reported an increase in blood neutrophil concentration at 8 and $12 \mathrm{~h}$ postinjection of LPS but in contrast there was no change in peripheral blood leukocyte differential count when LPS dosages of $25 \mathrm{ng}$ or less were used into joint (Palmer and Bertone, 1994).

An increase in the TNF- $\alpha$ concentration was observed when LPS was injected into the carpus at 3 and $1.5 \mathrm{~h}$ in groups $\mathrm{A}$ and $\mathrm{B}$, respectively, which were significantly different from the control joints. Billinghurst et al. (1995) observed a significant induction in TNF- $\alpha$ bioactivity in inflamed joints compared to the control, but without statistically significant differences. Besides, these authors noted that serial arthrocentesis, as judged by the responses in the control joints, did not have a significant effect on the synovial fluid TNF- $\alpha$ concentration. As observed by Hawkins et al. (1995), during synovitis, maximal TNF activities were seen at $2 \mathrm{~h}$ after LPS injection into the joint. These data are in agreement with May and Knottenbelt (1992) where TNF- $\alpha$ can be measured in plasma or serum 1 to $4 \mathrm{~h}$ after LPS administration. The observation of this study that TNF- $\alpha$ did not increase in blood after intra-articular administration of LPS is in according with Hawkins et al.(1993). The source of TNF- $\alpha$ is probably cells of the macrophage lineage infiltrating the synovial tissue (Hopkins and Meager, 1988) or either resident cells of synovial fluid (Hopkins, Meager, 1988; Billinghurst et al., 1995). Alternatively, enzymes released from the synovium may have little direct effect on cartilage breakdown but may incite the release of cytokines from adjacent synoviocytes and/or chondrocytes (Palmer and Bertone, 1994), as observed with the TNF- $\alpha$ high concentration in cartilage from joints with naturally occurring acute traumatic joint disease (Trumble et al., 2001).

During the experimental period, circulating TNF$\alpha$ concentration was not detected at any time point from the baseline values as observed by Hawkins et al. (1993) using greater dosage of LPS ( $3 \mu \mathrm{g} /$ joint). According these authors, this could be attributable to dilution by the large blood volume vs synovial fluid volume.

The volume of $5 \mathrm{ml}$ of $2 \%$ lidocaine $(100 \mathrm{mg}$ of lidocaine), as recommended for intra-articular anesthesia of carpus (Rose and Frauenfelder, 1982; Todhunter, 1992), which has a volume of $14.9 \pm 0.6$ of synovial fluid, resulted in a final dosage of $6.7 \mathrm{mg}$ of lidocaine $/ \mathrm{ml}$ of synovial fluid. In rabbits, Mikawa et al. (1994) used $2 \mathrm{mg} / \mathrm{kg}$ in a single dose of intravenous lidocaine $10 \mathrm{~min}$ before infusion of LPS and thereafter infused it at a rate of $2 \mathrm{mg} / \mathrm{kg} / \mathrm{h}$ until $6 \mathrm{~h}$ after the start of LPS administration and in another study (Nishina et al., 1995) the rabbits received 10min after the end of infusion of endotoxin, a bolus injection followed by continuous infusion of lidocaine $\quad(2 \mathrm{mg} / \mathrm{kg}+2 \mathrm{mg} / \mathrm{kg} / \mathrm{h})$. Others researchers (Takao et al., 1996), used the same dosage of lidocaine, but after exposing animals to $100 \%$ oxygen. Dogs (Fletcher and Ramwell, 1978) received a continuous infusion of lidocaine $(1 \mathrm{mg} / \mathrm{kg} / \mathrm{h})$ from $45 \mathrm{~min}$ before to $2 \mathrm{~h}$ after an $\mathrm{LD}_{60}$ dose of endotoxin.

These protocols above mentioned intended to evaluate the effects of lidocaine on the inflammatory response and specially on inflammatory cells, mainly polymorphonuclear granulocytes (PMNs) but also macrophages and monocytes (Hollmann and Durieux, 2000).

Some in vitro studies have shown that lidocaine impairs leukocyte antibacterial functions, reduces bacterial killing rates for $E$. coli in high concentrations $(2 \mathrm{mg} / \mathrm{ml})$ (Peck et al., 1985), and has the capacity to alter the function and the structure of human macrophages. Perhaps these alterations may be associated to the chemical structure of local anesthetics, such as demonstrated by Sasagawa (1991). As enzymes released from the synovium may incite the release of other inflammatory factors, such as 
cytokines, from adjacent synoviocytes and/or chondrocytes (Palmer and Bertone, 1994), it is possible that the inhibitory effect of lidocaine on chemotaxis was abrogated by the activity of defense cells of the joint as by many other inflammatory factors released by these cells. Local anesthetics, such as lidocaine, are known to block leukotrienes release, particularly $\mathrm{LTB}_{4}$, which play an important role in the early phase of inflammation (Hollmann and Durieux, 2000). So, as it was observed an increased leukocyte count in synovial fluid in group B, maybe the dose of lidocaine used here was not effective to reduce the $\mathrm{LTB}_{4}$ release, formed in PMN and monocytes, which is a potent leukoattractant and stimulator of PMN activity.

In the present study, lidocaine was administered immediately after LPS injection, which could account for the fact that there was no antiinflammatory effect of this drug.

No significant correlation could be demonstrated in any of the variables tested to the use of lidocaine at this dosage in this study. The results provide no support for the view that intraarticular lidocaine at this dosage, and timing post-injury, has an effect on synovitis.

\section{CONCLUSIONS}

Intra-articular injections of $1.5 \mathrm{ng}$ LPS in this experimental model of joint inflammation, created sufficient transient inflammation with increases in synovial fluid total nucleated cell count, total protein concentration associated with biochemical and enzyme concentration alterations, and a few clinical effects without non-weight bearing lameness. Lidocaine inhibited the increase in rectal temperature caused by LPS and delayed hemoconcentration, but did not prevent the increased synovial fluid protein concentration, the leukocyte response and TNF- $\alpha$ synthesis and release. Lidocaine did not prevent LPS-induced synovitis in this study.

\section{ACKNOWLEDGEMENTS}

Acknowledgements to Dr. Euclides Braga Malheiros (Faculdade de Ciências Agrárias e Veterinárias. Universidade Estadual Paulista UNESP - Jaboticabal, SP) for the statistical analyses.

\section{REFERENCES}

BILLINGHURST, R.C.; FRETZ, P.B.; GORDON, J.R. Induction of intra-articular tumor necrosis factor during acute inflammatory responses in equine arthritis. Equine Vet. J., v.27, p.208-216, 1995.

BURROWS, G.E. Equine E. coli endotoxemia: comparison of intravenous and intra-peritoneal endotoxin administration. Am. J. Vet. Res., v.40, p.991-999, 1979.

CAMPBELL, I.K.; PICCOLI, D.S.; ROBERTS, M.J. et al. Effects of tumor necrosis factor $\alpha$ and $\beta$ on resorption of human articular cartilage and production of plasminogen activator by human articular chondrocytes. Arthritis Rheum., v.33, p.542-552, 1990.

COPPO, J.A.; SANDOVAL, G.L.; PEREZ, O.A. et al. Análisis de líquido sinovial para la tipificación de artropatías del equino. Rev. Med. Vet., v.69, p.77-87, 1988.

DAYER, J.M.; BEUTLER, B.; CERAMI, A. Cachectin/tumor necrosis factor stimulates collagenase and prostaglandin $\mathrm{E}_{2}$ production by human synovial cells and dermal fibroblasts. $J$. Exp. Med., v.162, p.2163-2168, 1985.

ESPERVIK, T.; NISSEN-MEYER, J. A highly sensitive cell line, WEHI 164, clone 13, for measuring cytotoxic factor/ tumor necrosis factor from human monocytes. J. Immunol. Method, v.95, p.99-105, 1986.

FESSLER, J.F.; BOTTOMS, G.D.; COPPO, G.L. et al. Plasma endotoxin concentrations in experimental and equine subjects. Equine Vet. J. (Supplement), v.7, p.24-28, 1989.

FIRTH, E.C.; WENSING, T.; SEUREN, F. An induced synovitis disease model in ponies. Cornell Vet., v.77, p.107-118, 1987.

FLETCHER, J.R.; RAMWELL, P.W. E. coli endotoxin shock in the dog; treatment with lidocaine or indomethacin. Br. J. Pharmacol., v.64, p.185-191, 1978.

GARNETT, M.E.; GODIN, D.V.; TUCHEK, J.M. In vivo and in vitro studies of bacterial endotoxin-membrane interactions and the effects of membrane-active agents. Br. J. Pharmacol., v.83, p.15-21, 1984. 
HAWKINS, D.L.; CARGILE, J.L.; MACKAY, R.J. et al. Effect of tumor necrosis factor antibody on synovial fluid cytokine activities in equine antebrachiocarpal joints injected with endotoxin. Am. J. Vet. Res., v.56, p.1292-1299, 1995.

HAWKINS, D.L.; MACKAY, R.J.; GUM, G.G. et al. Effect of intra-articularly administered endotoxin on clinical signs of disease and synovial fluid tumor necrosis factor, interleukin 6 , and prostaglandin E2 values in horses. Am. J. Vet. Res., v.54, p.379-386, 1993.

HENRY, M.M.; MOORE, J.N. Equine endotoxemia. In: SMITH B.P.(Ed.). Large animal internal medicine. St.Louis: Mosby, 1990. p.619-835.

HOLLMANN, M.W.; DURIEUX, M.E. Local anesthetics and the inflammatory response. Anesthesiology, v.93, p.858-875, 2000.

HOPKINS, S.J.; MEAGER, A. Cytokines in synovial fluid: II. The presence of tumour necrosis factor and interferon. Clin. Exp. Immunol., v.73, p.88-92, 1988.

HUSSNI, C.A.; LOPES, R.S.; NICOLETTI, J.L.M. et al. Efeitos da artrocentese carpal seriada em equinos. In: CONGRESSO PANAMERICANO DE CIÊNCIAS VETERINÁRIAS, Campo Grande, 1996. Proceedings... Campo Grande, 1996.

KIRICHENKO, L.L.; MASENKO, V.P.; NIKITIN, A.E. et al. Effects of anti-arrhythmia preparations on thrombocytic and vascular hemostasis. Terapeuticheskii Arkhiv., v.58, p.7072, 1986.

KORTH, R.; MONGOLD, H.K.; MURAMATSU, T. et al. Unsaturated 1-0-alkyl2-acetyl-sn-glycerol-3-phosphocholines

(unsaturated platelet activating factor): aggregation of human platelets after incubation with indomethacin, creatinephosphate/creatine phosphokinase, xylocaine and hirudine, and serotonin release after incubation with indomethacin. Chem. Phys. Lipids, v.36, p.209214, 1985.

KUNZE, H.; NAHAS, N.; TRAYNOR, J.R. et al. Effects of local anaesthetics on phospholipases. Bioch. Bioph. Acta, v.441, p.93102, 1976.
MAY, A.S.; KNOTTENBELT, D.C. Tumour necrosis factor - physiology and pathology. Equine Vet. Educ., v.4, p.62-65, 1992.

McILWRAITH, C.W. Diseases of joints, tendons, ligaments, and related structures. In: STASHAK, T.S. (Ed.). Adam's lameness in horses. 2.ed. Philadelphia: Lea \& Febiger, 1987. p.339-485.

McILWRAITH, C.W. Ultrastructural and histochemical studies of filipin induced equine arthritis. In: TODHUNTER R.J.; LUST, G. Pathophysiology of synovitis: Clinical signs and examination in horses. Comp. Cont. Educ. Pract. Vet., v.12, p.980-992, 1990.

McILWRAITH, C.W.; FESSLER, J.F.; BLEVINS, W.E. et al. Experimentally induced arthritis of the equine carpus: clinical determinations. Am. J. Vet. Res., v.40, p.11-20, 1979.

MIKAWA, K.; MAEKAWA, N.; NISHINA, K. et al. Effect of lidocaine pretreatment on endotoxin-induced lung injury in rabbits. Anesthesiology, v.81, p.689-699, 1994.

NISHINA, K.; MIKAWA, K.; MAEKAWA, N. et al. Does early posttreatment with lidocaine attenuate endotoxin-induced acute injury in rabbits? Anesthesiology, v.83, p.169-177, 1995.

OHSAKA, A.; SAIONJI, K.; SATO, N. et al. Local anesthetic lidocaine inhibits the effect of granulocyte colony stimulation factor on human neutrophil functions. Exp. Hemat., v.22, p.460466, 1994.

OWENS, J.G.; KAMERLING, S.G.; STANTON, S.R. et al. Effects of pretreatment with ketoprofen and phenylbutazone on experimentally induced synovitis in horses. Am. J. Vet. Res., v.57, p.866-874, 1996.

PALMER, J.L.; BERTONE, A.L. Experimentally induced synovitis as a model for acute synovitis in the horse. Equine Vet. J., v.26, p.492-495, 1994.

PAUL, H.; CLAYBURNE, G.; SCHUMACHER, H.R. Lidocaine inhibits leukocyte migration and phagocytosis in monosodium urate crystal-induced synovitis in dogs. J. Rheumat., v.10, p.434-439, 1983.

PECK, S.L.; JOHNSTON, R.B.; HORWITZ, L.D. Reduced neutrophil superoxide anion 
release after prolonged infusion of lidocaine. $J$. Pharmacol. Exp. Ther., v.235, p.418-422, 1985.

PERSSON, L. On the synovia in horses: A clinical and experimental study. Acta Vet. Scand., Suppl., v.35, p.1-75, 1971.

PRICE, J.S.; SYMONS, J.Á.; RUSSEL, R.G.G. Cytokines: inflammatory mediators of joint disease. Equine Vet. J., v.24, p.78-80, 1992.

ROSE, R.J.; FRAUENFELDER, H.C. Arthrocentesis in the horse. Equine Vet. J., v.14, p.173-177, 1982.

SAKLATVALA, J. Tumor necrosis factor $\alpha$ stimulates resorption and inhibits synthesis of proteoglycan in cartilage. Nature, v.322, p.547549, 1986.

SASAGAWA, S. Inhibitory effects of local anesthetics migration extra-cellular release of lysosomal enzyme and superoxide anion production in human polymorphonuclear leukocytes. Immunopharmacol. Immunotoxicol., v.13, p.607-622, 1991.

SINGH, A.P. Effect of intra-articular injection of local anaesthetics and arthrocentesis on bovine synovia. Indian J. Anim. Sci., v.61, p.1190-1192, 1991.

SNYDERMAN, R. Mechanisms of inflammation and leucocyte chemotaxis in the rheumatic diseases. Med. Clin. North Am., v,70, p.217-234, 1986.

STASHAK, T.S. Adam's lameness in horses. 2.ed. Philadelphia: Lea \& Febiger, 1987. p106.
TAKAO, Y.; MIKAWA, K.; NISHINA, K. et al. Lidocaine attenuates hyperoxic lung injury in rabbits. Acta Anaesthesiol. Scand., v.40, p.318325, 1996.

TODHUNTER, R.J. Diagnostic principles of joint disease. In: AUER, J.A. (Ed.). Equine surgery. Philadelphia: W. B. Saunders, 1992. p.866-882.

TODHUNTER, R.J.; LUST, G. Pathophysiology of synovitis: Clinical signs and examination in horses. Comp. Cont. Educ. Pract. Vet., v.12, p.980-992, 1990.

TRUMBLE, T.N.; TROTTER, G.W.; OXFORD, J.R.T. Synovial fluid gelatinase concentrations and matrix metalloproteinase and cytokine expression in naturally occurring joint disease in horses. Am. J. Vet. Res., v.62, p.1467-1477, 2001.

TULAMO, R.M.; BRAMLAGE, L.R.; GABEL, A.A. Sequential clinical and synovial fluid changes associated with acute infectious arthritis in the horse. Equine Vet. J., v.21, p.325-331, 1989.

USER'S guide: statistical analysis system. Release 6.11. Cary, NC: SAS Institute, 1996.

VAN PELT, R.W. Interpretation of synovial fluid findings in the horse. J. Am. Vet. Med. Assoc., v.165, p.91-95, 1974.

WAGNER, A.E.; McILWRAITH, C.W.; MARTIN, G.S. Effect of intra-articular injection of orgotein and saline solution on equine synovia. Am. J. Vet. Res., v.43, p.549-597, 1982. 